\title{
Racikan Minuman Jamur Tiram (Pleurotus ostratus) sebagai Peningkat Kesehatan Tubuh
}

\author{
Oyster Mushroom Drink Concoction (Pleurotus ostratus) as a Body Health Enhancer
}

\section{Uce Lestari ${ }^{1 *}$ \\ Damris Muhammad ${ }^{2}$ \\ Ade Adriadi 3 \\ Minarni ${ }^{2}$ \\ 1Department of Pharmacy, Universitas Jambi, Muaro Jambi, Jambi, Indonesia \\ 2Department of Chemistry, Universitas Jambi, Muaro Jambi, Jambi, Indonesia}

${ }^{3}$ Department of Biology, Universitas Jambi, Muaro Jambi, Jambi, Indonesia

email: ucelestari@unja.ac.id

\section{Kata Kunci}

Formulasi

Jamur tiram

Kesehatan

Minuman

Keywords:

Formulation

Oyster mushroom

Health

Drink

Received: April 2021

Accepted: September 2021

Published: October 2021

\begin{abstract}
Abstrak
Kelurahan Tanjung Johor terletak di Kecamatan Pelayangan Kota Jambi dan merupakan salah satu desa binaan Universitas Jambi yang memiliki potensi sumber daya alam besar, namun mata pencaharian masyarakat masih mayoritas sebagai petani karet dan sawit. Salah satu potensi yang terdapat di kelurahan ini adalah limbah dari tandan kosong sawit dan dimanfaatkan sebagai pertanian jamur tiram. Jamur tiram yang dihasilkan belum diolah menjadi minuman Kesehatan, hanya sebagai bahan masakan. Hasil pembinaan dan kerja sama dari dosen Universitas Jambi seperti pengenalan manfaat jamur tiram untuk peningkatan kesehatan tubuh di kelurahan ini sudah dilakukan, namun produksi jamur tiram belum dilaksanakan. Dengan melihat potensi ini, muncul ide untuk membuat minuman kesehatan dari jamur tiram. Tujuan kegiatan pengabdian kepada masyarakat ini adalah mampu memberi nilai jual jamur tiram hasil pertanian dan penanganan pascapanen, meningkatkan pengetahuan masyarakat mengenai manfaat jamur tiram, dan memaksimalkan sumber daya manusia kelurahan Tanjung Johor. Metode yang digunakan yaitu penyuluhan jamur tiram dan pembuatan minuman kesehatan. Kegiatan ini menghasilkan produk olahan dari jamur tiram seperti minuman kesehatan yang dapat meningkatkan nilai jual dari jamur tiram, serta meningkatkan kreativitas sumber daya manusia di Kelurahan Tanjung Johor, Kecamatan Pelayangan, Kota Jambi.
\end{abstract}

\begin{abstract}
Tanjung Johor sub-district is located in the District of Service of Jambi City and is one of the guided villages of the University of Jambi, which has great natural resource potential. However, the community's livelihoods are still mostly rubber and oil palm farmers. One of the potentials in this village is waste from empty palm oil bunches and used as oyster mushroom farming. The resulting oyster mushroom has not been processed into a health drink, only as a cooking ingredient. The results of guidance and collaboration from Jambi University lecturers, such as introducing the benefits of oyster mushrooms for improving body health in this village, have been carried out, but the production of oyster mushrooms has not been carried out. By seeing this potential came the idea to make a healthy drink from oyster mushrooms. The purpose of this community service activity is to provide selling value for oyster mushrooms from agriculture and post-harvest handling, increase public knowledge about the benefits of oyster mushrooms and maximize human resources in Tanjung Johor village. The method used is oyster mushroom counseling and making health drinks. This activity produces processed products from oyster mushrooms such as health drinks that can increase the selling value of oyster mushrooms and increase the creativity of human resources in Tanjung Johor Village, Pelayangan District Jambi City.
\end{abstract}




\section{PENDAHULUAN}

Kelurahan Tanjung Johor merupakan kelurahan yang terletak di Kecamatan Pelayangan, Kota Jambi yang merupakan salah satu desa binaan Universitas Jambi dan memiliki potensi sumber daya alam yang besar, namun mata pencaharian masyarakat masih mayoritas sebagai petani karet dan sawit. Belum ada yang memanfaatkan tandan kosong sawit sebagai pertanian jamur tiram. Dengan adanya potensi ini maka pertanian jamur tiram akan memiliki potensi yang besar untuk lebih maju (Rini \& Amaliyah, 2019).

Jamur tiram (Pleurotus ostreatus) merupakan genus yang banyak dikonsumsi oleh masyarakat di seluruh dunia karena rasanya enak, nilai gizi yang tinggi, dan sumber nutrisi (Cheung, 2013; Deepalakshmi \& Mirunalini, 2014). Jamur tiram memiliki kandungan karbohidrat yang tinggi, seperti oligosakarida diantaranya trehalose dan polisakarida seperti kitin, $\beta$-glukan, dan manan. Kandungan $\beta$-glukan pada polisakarida sangat tinggi ( $>80 \%$ berat kering) yang memiliki efek biofarmakologi yang bermanfaat bagi kesehatan (Jantaramanant et al. 2014) sebagai bahan imunologi (Christopher 2005; Synytsya et al., 2009; Oloke \& Adebayo, 2015) seperti antidiabetes, antibakteri, antikolesterol, antiartritik, antioksidan, antikanker, kesehatan mata, aktivitas antiviral (Deepalakshmi \& Mirunalini, 2014), dan dapat mereduksi konsentrasi gula darah (Jakubik et al., 2012). Hasil pembinaan dan kerja sama dari dosen Universitas Jambi seperti pengenalan manfaat jamur tiram untuk peningkatan kesehatan tubuh di kelurahan ini sudah dilakukan, namun produksi jamur tiram belum dilaksanakan. Dengan melihat potensi ini, maka muncul ide untuk membuat minuman kesehatan dari jamur tiram. Hasil penelitian sebelumnya menunjukkan bahwa pemasakan jamur tiram sudah terbukti tidak merusak kandungan $\beta$-glukan (Masitoh et al., 2015; Tjokrokusumo, 2015).
Tujuan kegiatan pengabdian kepada masyarakat ini adalah mampu memberi nilai jual jamur tiram hasil pertanian dan penanganan pascapanen, meningkatkan pengetahuan masyarakat mengenai manfaat jamur tiram, dan memaksimalkan sumber daya manusia kelurahan Tanjung Johor. Metode yang digunakan dalam pelatihan ini, yaitu penyuluhan tentang jamur tiram dan pembuatan minuman kesehatan. Kegiatan ini menghasilkan produk olahan dari jamur tiram seperti minuman kesehatan yang dapat meningkatkan nilai jual dari jamur tiram, serta meningkatkan kreativitas sumber daya manusia di Kelurahan Tanjung Johor, Kecamatan Pelayangan, Kota Jambi.

\section{METODOLOGI}

Pelatihan dilaksanakan pada hari sabtu tanggal 22 Agustus 2020 di salah satu rumah masyarakat kelurahan Tanjung Johor, Kecamatan Pelayangan, Kota Jambi. Bahan yang digunakan dalam pelatihan ini adalah jamur tiram, gula, kayu manis, pewarna makanan dan air. Alat yang digunakan adalah peralatan untuk merebus, botol pengemas, dan panci penyimpan sari jamur tiram.

Program kerja yang dilaksanakan dalam kegiatan pengabdian kepada masyarakat sebagai berikut:

1. Memberikan penyuluhan kepada masyarakat tentang manfaat jamur tiram dalam peningkatan kesehatan

Tim PPM mempresentasikan tentang kandungan nutrisi dan vitamin yang terdapat pada jamur tiram antara lain rendah kalori, rendah lemak, serat, protein, zat besi, niacin, vitamin $\mathrm{D}$, riboflavin, kalium, vitamin B6, vitamin B, thiamin, asam folat, magnesium, vitamin $\mathrm{C}$, asam Pantotenat, asam amino, antioksidan. Dari kandungan nutrisi, gizi dan vitamin pada jamur tiram dapat bermanfaat bagi kesehatan diantaranya meningkatkan sistem kekebalan tubuh, menurunkan kadar kolesterol, 
mengurangi risiko kanker, mengurangi tekanan darah tinggi, mengurangi efek peradangan, meningkatkan kesehatan otak, memiliki efek antibakteri, memiliki efek antioksidan, meningkatkan kesehatan tulang, dan menjaga kesehatan jantung

2. Memberikan pelatihan pembuatan minuman kesehatan jamur tiram

Bahan yang digunakan pada pembuatan minuman kesehatan jamur tiram antara lain Jamur tiram $1 \mathrm{~kg}$, gula pasir secukupnya, kulit kayu manis 3 batang, perasa dan pewarna makanan, jika perlu ditambahkan nenas 1 buah, jeruk atau lemon 1 buah, air bersih secukupnya.

Cara pembuatan minuman kesehatan jamur tiram yaitu dengan timbang jamur tiram sebanyak $1 \mathrm{~kg}$, kemudian disuir-suir hingga menjadi bagian yang kecil. Rebuslah jamur tiram dengan air secukupnya hingga matang, angkat lalu tiriskan. Masukkan jamur tiram kedalam baskom yang telah berisi air lalu cuci dan bilas beberapa kali dengan air hingga jamur tidak berbau lagi lalu keringkan. Masukkan jamur tiram kedalam blender lalu tambahkan sedikit air dan dihaluskan hingga menjadi bubur. Rebuslah bubur jamur tiram dengan air secukupnya hingga matang dan diaduk terus. Siapkan penyaring yang sangat halus kemuadian saringlah bubur jamur tiram hingga didapatkan sari jamur.

Buanglah ampas jamur tiram. Rebus kembali sari jamur tiram tambahkan kulit kayu manis 3 batang. Tambahkan gula pasir secukupnya sesuai selera. Bagi menjadi dua bagian sari jamur tiram, bagian pertama tambahkan perasa dan pewarna stroberi sedangkan bagian kedua. Tambahkan pewarna dan perasa pandan lalu dinginkan, jika telah dingin masukkan kedalam botol kaca. Botol kaca harus direbus terlebuh dahulu agar steril dan bersih.
Minuman kesehatan jamur titam JATIRA SUKE pun siap diminum.

\section{HASIL DAN PEMBAHASAN}

Hasil yang dicapai dalam kegiatan pengabdian kepada masyarakat ini adalah terlaksananya pelatihan pembuatan minuman kesehatan jamur tiram yang memberikan pengetahuan dan skill bagi masyarakat Tanjung Johor tentang pemanfaatan jamur tiram bagi peningkatan kesehatan tubuh. Kegiatan ini sudah melakukan koordinasi awal dengan ibu RT 04 Kelurahan Tanjung Johor, kecamatan Pelayangan, Kota Jambi dan telah mendapatkan izin rekomendasi untuk mengadakan pelatihan dari tim gugus covid 19 dan camat Pelayangan, dikarenakan kegiatan PPM ini diadakan pada saat pandemi covid 19 dengan ketentian mengikuti protokol kesehatan pada pelaksanaanya.

Hasil kesepakatan dengan ibu RT setempat dihasilkan rencana kegiatan pelatihan kepada masyarakatan kelurahan Tanung Johor RT 04 berdasarkan kebutuhan untuk pemanfaatan jamur tiram sebagai minuman kesehatan bagi peningkatan kesehatan tubuh. Hasil kegiatan wawancara dan diskusi awal bahwa masyarakat Tanjung Johor belum mengenal manfaat jamur tiram bagi kesehatan tubuh. Saat ini mereka memanfaatkan jamur tiram hanya sebagai bahan masakan saja. Oleh karena itu, kegiatan pengabdian ini kemudian dirancang dan dikemas dengan membuat program pelatihan minuman kesehatan.

Kegiatan penyuluhan kepada masyarakat Tanjung Johor dilakukan setelah adanya survei awal. Adapun peserta penyuluhan disiapkan oleh pihak kelurahan yang merupakan warga sekitar. Dalam pelaksanaan kegiatan ini masyarakat sangat antusias mengikuti pelatihan dan penyuluhan mengenai pembuatan minuman kesehatan jamur tiram serta manfaat kandungannya, seperti ditunjukkan pada Gambar 1. 


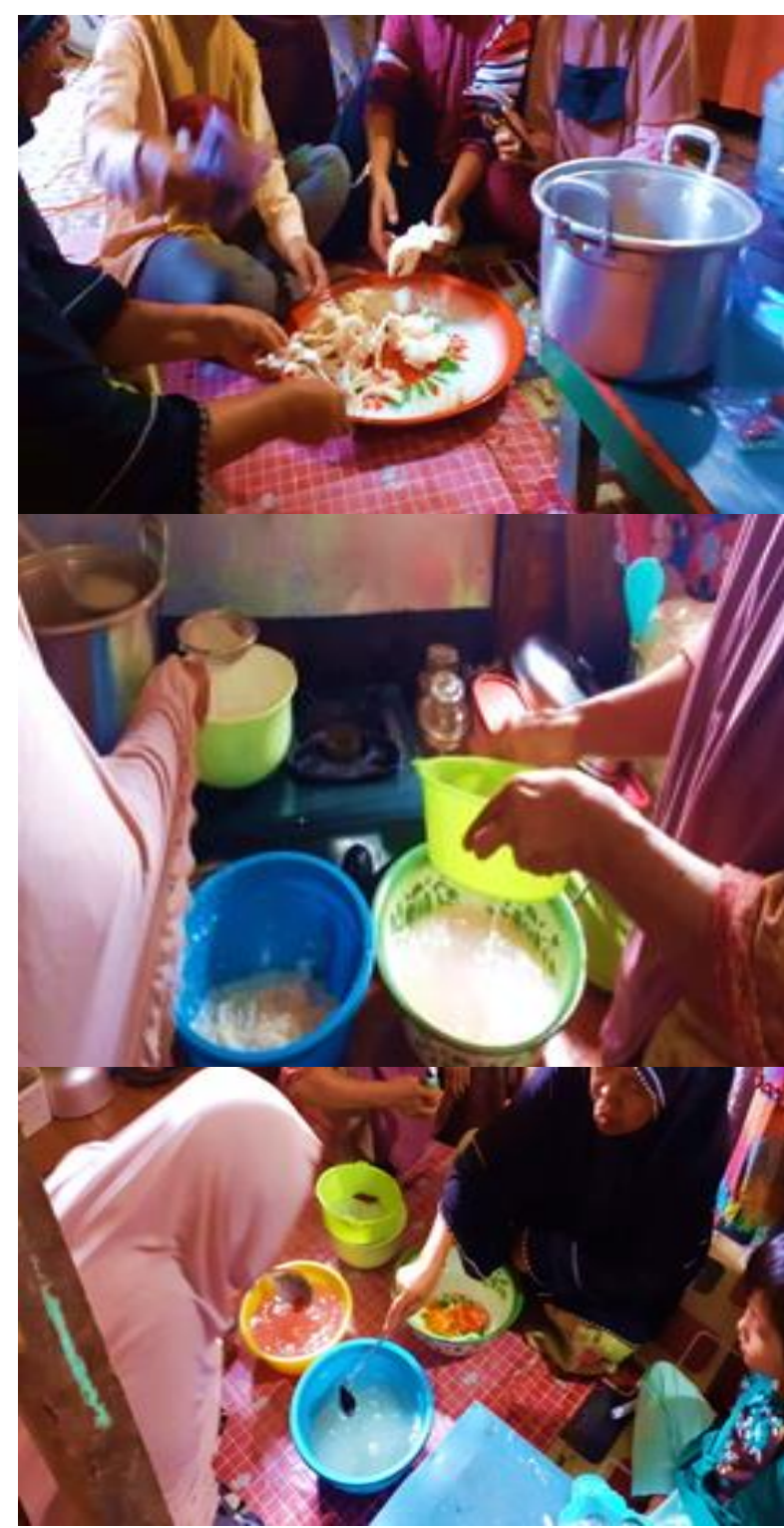

Gambar 1. Pelatihan Pembuatan minuman kesehatan jamur tiram

Hasil kegiatan pelatihan dan penyuluhan ini memberikan masyarakat pengetahuan lebih tentang jamur tiram, baik dari segi manfaat kesehatan maupun tentang pemasaran jamur tiram, sehingga dapat meningkatkan minat masyarakat terhadap konsumsi jamur tiram bagi kesehatan. Jamur tiram memiliki kandungan $\beta$-glukan yang cukup tinggi yang dapat dimanfaatkan sebagai bahan imunologi yang bermanfaat bagi kesehatan. Selain itu, kami bersama ibuibu PKK Kelurahan Tanjung Johor akan melakukan diversifikasi pangan untuk meningkatkan nilai jual dari jamur tiram dengan pembentukan UMKM minuman kesehatan, sehingga dapat meningkatan pendapatan dan memperluas lapangan pekerjaan bagi masyarakat Tanjung Johor dan tidak hanya sebagai petani karet dan sawit saja. Diakhir acara dilakukan foto bersama bersama tim PPM Desa Binaan Universitas Jambi dengan peseta penyuluhan masyarakat Tanjung Johor.

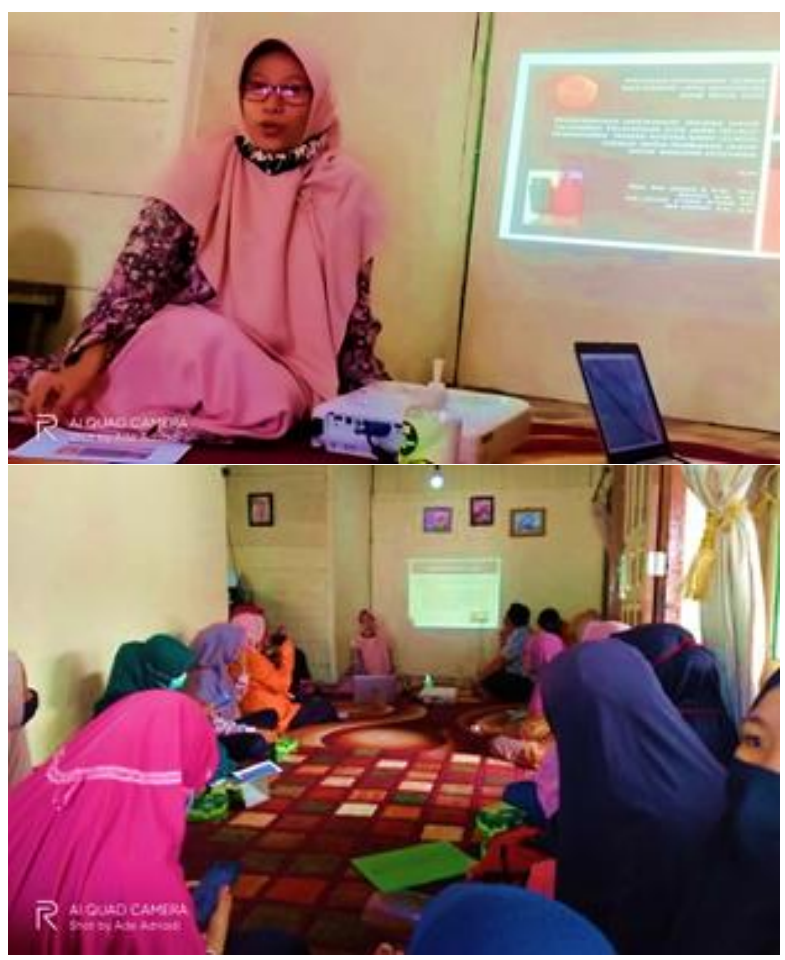

Gambar 2. penyuluhan tentang manfaat jamur tiram

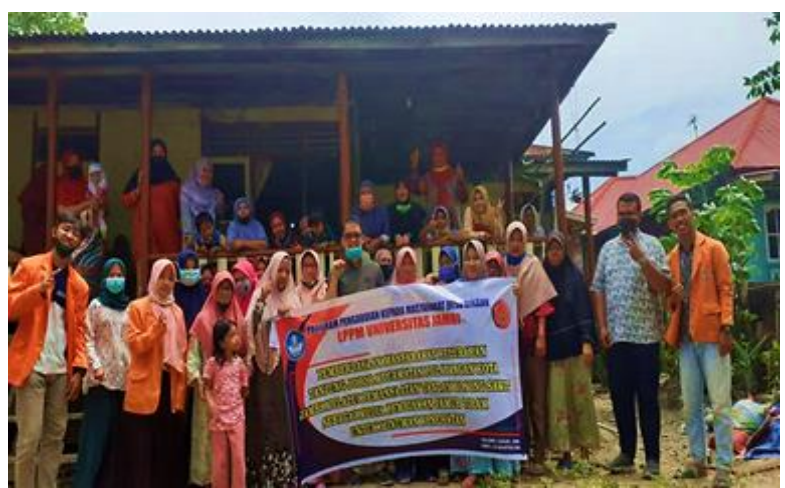

Gambar 3. Foto Bersama

\section{KESIMPULAN}

Hasil dari kegiatan pelatihan pembuatan minuman kesehatan jamur tiram dapat disimpulkan bahwa kegiatan ini memberikan pengetahuan lebih tentang jamur tiram dan manfaatnya. selain itu dapat 
meningkatkan daya jual jamur tiram dalam produk olahan seperti minuman kesehatan. Dengan adanya kegiatan pelatihan ini juga meningkatkan kreativitas sumber daya di Kelurahan Tanjung Johor.

\section{UCAPAN TERIMA KASIH}

Terima kasih untuk pihak yang telah membantu baik dana ataupun support terutama pihak Lurah Tanjung Johor, Camat Pelayangan, RT 04 Kelurahan Tanjung Johor dan Rektor Universitas Jambi, LPPM Universitas Jambi dan semua pihak yang terkait sehingga pelaksanaan PPM ini terlaksana dengan baik dan lancar.

\section{REFERENSI}

Cheung, P.C.K. 2013. Mini-review on edible mushrooms as source of dietary fiber: Preparation and health benefits. Food Science and Human Wellness. 2(3-4):162-166. https://doi.org/10.1016/j.fshw.2013.08.001

Christopher, H. 2005. Medicinal Mushrooms for Cellular Defense, Immunity $\mathcal{E}$ Longevity. California: University of California Press.

Deepalakshmi, K., Mirunalini, S. 2014. Pleurotus ostreatus: an oyster mushroom with nutritional and medicinal properties. Journal of Biochemical Technology. 5(2):718-726.

Jakubik, J., Hnatova, M., Bakos, D. 2012. Beta-1,3/1,6-DGlucan from Oyster Mushroom to Purified Polysaccharide. Chemicke Listy. 106: 1148-1149.

Jantaramanant, P., Sermwittayawong, D., Noipha, K., Towatana, H.N., Wititsuwannakul, R. 2014. $\beta$ glucan-containing polysaccharide extract from the grey oyster mushroom [Pleurotus sajorcaju (Fr.) Sing.] stimulates glucose uptake by the L6 myotubes. International Food Research Journal. 21(2):779-784.

Masitoh, Ariyanti, L., Firdaus, F.H., Irma, A., Apriliana, E., Irzaman, Kurniati, M., Risanti, M. 2015. Formulasi Minuman Kesehatan Ekstrak Jamur Tiram Putih (Pleurotus ostratus) Kaya $\beta$-Glukan. Agrokreatif: Jurnal Ilmiah Pengabdian kepada Masyarakat. 1(2):96-100. https://doi.org/10.29244/agrokreatif.1.2.96100

Oloke, J.K., Adebayo, E.A. 2015. Effectiveness of Immunotherapies from Oyster Mushroom (Pleurotus species) in the Management of Immunocompromised Patients. International Journal of Immunology. 3(2-1):8-20.

Rini, A.D., Amaliyah. 2019. Strategi Pengembangan Agribisnis Jamur Timur Wujud Penguatan Ekonomi Lokal. JEPA (Jurnal Ekonomi Pertanian dan Agribisnis). 3(2):311-324. https://doi.org/10.21776/ub.jepa.2019.003.02 .8

Synytsya, A., Míčková, K., Synytsya, A., Jablonský, I., Spěváček, J., Erban, V., Kováříková, E., Čopíková, J. 2009. Glucans from fruit bodies of cultivated mushrooms Pleurotus ostreatus and Pleurotus eryngii: Structure and potential prebiotic activity. Carbohydrate Polymers. 76(4):548-556.

https://doi.org/10.1016/j.carbpol.2008.11.021

Tjokrokusumo, D. 2015. Diversity of edible mushrooms on their beta glucan content and health benefits. Prosiding Seminar Nasional Masyarakat Biodiversitas Indonesia. 1(6):1520-1523. https://doi.org/10.13057/psnmbi/m010646 